\title{
Artur Rodziewicz
}

Jagiellonian University, Kraków, Poland

\section{Milete min Êzîd. The Uniqueness of the Yezidi Concept of the Nation*}

\begin{abstract}
Both the current increasing nationalistic discourse of the Yezidis and the discussion about their "Kurdishness" result from the growing political significance of the Kurds and the inclusion of the Yezidis into the geopolitical game in the Iraqi Kurdistan region. The paper concerns the traditional Yezidi understanding of their millet, still valid, but starting to change, which is based on the mystical and metaphysical ideas incompatible with the approach preferred by contemporary political science.
\end{abstract}

Keywords: Yezidis, Kurds, nationalism, millet, Sunna, Quraysh, Umayyads

Creating the English-language version of the journal "Securitologia" is financed under contract No. 724/P. DUN/2018 from the funds allocated by the Minister of Science and Higher Education for dissemination of science.

\footnotetext{
*Work on this article was supported by the Polish National Science Centre, grant: DEC-2016/20/S/HS1/00055. Its main theses were presented at the conference The Role of the Kurds in the Middle East (Warsaw 14 May 2018). The threads I am discussing here, I also develop, more extensively, in the article The Nation of the Sur. The Yezidi Identity Between Modern and Ancient Myth (Rodziewicz 2018a).
} 


\section{A pawn in the game}

We are witnessing a discussion, or even a sharp dispute, whether the Yezidis should be regarded as Kurds or not (Rodziewicz 2016, pp. 155-157). Today, even among the Yezidis there is no consensus as to their self-identification. Some of them identify with the Kurds and call themselves "Yezidi-Kurds", others with the "Arabs", the "Iraqis" or even the "Kurdistani", as recently stated Haider Shasho, the Commander of the Ezidkhan Protection Units (Nicolaus, Yuce 2017, p. 217). Some consider themselves a separate Yezidi nation, which applies to a large extent to the diaspora living in Georgia (Pirbari, Rzgojan 2014, Rodziewicz 2017; 2018 b) and primarily in Armenia, where the state officially recognises the Yezidis as a separate non-Kurdish ethnos. During my field researcht in the areas inhabited by the Yezidis, I met representatives of each of these positions.

The majority of the Yezidis live in the Kurdistan Region of Iraq and, according to the second Article of the Iraqi Constitution, which declares Islam as the official state religion, they are not perceived in Iraq as a separate ethnic entity (such as the Turkomans, Assyrians and Chaldeans), but only as a religious one (along with Christians and "Mandi Sabeans"). This fact does not help them to build their own separate identity. The self-identification of the Yezidis is hampered by the fact that, due to the areas they inhabit, they have become part of an international game related to the Kurdish struggle for the independence of Kurdistan. Both the Iraqi state and the government of the Kurdistan region have no interest in creating an independent community. Therefore, the question of how the Yezidis define themselves with the Kurds is not only a theoretical issue but above all a political one. One can conclude that, depending on whether they would be defined as Kurds or not, they could be:

- a Kurdish force supporting other Kurds in the struggle for independence;

- an independent factor, a partner for the Kurds to the distribution of power in Iraqi Kurdistan;

- a hostile force against the Kurds.

The Yezidis are aware of these consequences, and that is why many of them remained neutral during the Iraqi Kurdistan Independence Referendum in 2017. However, at the same time, the anti-Kurdish sentiment is growing among them, especially as an effect

\footnotetext{
$\dagger$ In the years 2014-2018, I spent much time in areas inhabited by the Yeizids living among them - in Iraq, Turkey, Georgia and Armenia, where I observed Yezidi religious festivals and conducted interviews with representatives of all Yazidi castes - Pirs, Sheikhs and Murids. Two of them I have published in "Fritillaria Kurdica. Bulletin of Kurdish Studies" (Rodziewicz 2017; 2017-2018).
} 
of the genocide in Shingal. They accuse the Kurds of not defending them, that by withdrawing Peshmerga forces from Shingial they gave the green light to Islamic State (Murad 2017). At the same time, many Yezidis who try to cooperate with the Kurds are accused by part of the community of collaborating and promoting Kurdish interests over the Yezidis'. During my field research in Iraqi Kurdistan, I often encountered such an opinion.

The Kurds, in turn, realised that convincing the Yezdis of their "Kurdishness" would make it easier for them to pursue a policy that is not only military and economic but also cultural. The background for this was prepared before the Second World War when the Kurdish intelligentsia tried to describe the Yezidi religion as the original religion of all Kurds (Bedir-Khan 1928). They were looking for a base, a common nucleus, for the construction of a pan-Kurdish idea. Furthermore, the Arabs were aware of the "usefulness" of the Yezidis for their political goals. Especially during Saddam Hussein's regime they tried to convince the Yezidis that they are Arabs (Allison 2008, p. 2; 2014, pp. 103-108; Murad 2017, p. 4, 21, 40). Thus, numerous publications from that period emphasised the fact that the chief reformer (or initiator) of Yezidism, Sheikh Adi ibn Musafir, was not a Kurd, but an Arab, a descendant of the Umayyads (Chol 1973).

\section{The Yezidi millet}

To answer the question of whether the Yezidis are an independent nation or a part of another or other nations, one should first of all look at how they define their community when they do not use the terminology of modern Western political science and contemporary political discourse. Unfortunately, the modern scientific approach imposes a specific (secular or even atheistic) way of thinking, which ignores religious perspective which is, in my view, crucial to understanding the essence of the Yezidi community that is strictly connected with their beliefs. Thus it may be helpful to refer to oral tradition, especially to religious hymns and phrases that have remained unchanged for a long time. Given that for long tracts of time the Yezidis were not literate (because of a religious ban on writing), this seems particularly pertinent.

One of the most frequent self-declarations of the Yezidis is an enigmatic phrase, the first part of which was mentioned in the title of this paper: 


\section{Milete min Êzîd}

Dîne min Şerfedîn

Its beginning part concerns the millet, while the second deals with religion - dîn. This utterance shows that the Yezidis distinguish the name of their community from the name of their religion. In order to realise how they perceive this community and to address the significance that their millet is $\hat{E}_{z} \hat{\imath} d$, one should try at first to understand their perception of the term millet and investigate whether it differs from its colloquial use in the Middle East.

Millet, a word of Arabic origin, in modern Kurdish generally means "nation" or "people" (Chyet 2003, p. 387). However, it originally denoted "religion" and "religious community" (Richardson 1777, p. 1834-1835; Ursinus 1993; Braude 2014, p. 65-86), as for example in the Quranic phrase describing the Jews as "the people/religion of Abraham" ("Millat Ibrahim") or in the Arabic/Persian name for Christians as "the People of the Messiah" ("Al-milla al-Masibiyya" / "Mellat-e Masibiye").

This word is present in the oldest Yezidi poetry, especially in the sacred hymns (Qewls) probably dating back to the 12th and 13th centuries, surrounded by great reverence and recited during the main ceremonies (Rodziewicz 2018c). In these works, composed in Kurmanji but also containing a lot of Arabic terms, it is repeatedly mentioned that 72 millets were born from Adam and Eve. I will refer only to two fragments (for other examples, see Rodziewicz 2018a, pp. 280-283) from the group of the most important Yezidi hymns, called Qewlê Beranî (Omarkhali 2017, p. 102). One of them is the Qewlê Zebûnî Meksûr, The Hymn of the Weak Broken One. In stanza 42 (Rodziewicz 2018d) it is stated that:

Ji Adem wê bûn coqete, Jê vavartin heftê û du milete.
From Adam groups [of people] sprang, Seventy-two nations were separated from him.

Similarly in the Qewlê Qere Ferqan, The Hymn of the Black Furqan, stanza 33 (Kreyenbroek, Rashow 2005, p. 100):

Min ji Adem vevartibûn heftî û du milete.

From Adam, I brought forth the seventy-two nations. 
According to the Yezdi belief, they do not belong to this group, because they are a separate race or nation, the progeny of Adam alone, and more precisely his son, Shehid ben Jarr (and a houri named Layla), who was conceived without the participation of Eve (Spät 2002). The content of the Yezidi myths, which have been in force for centuries, clearly reflects their views about the relationship of their community to other groups. These beliefs are manifested in the strict prohibition of exogamy, entering into marriage with any of these 72 nations. Also, the number of genocides (ranging from 72 to 74 ) often cited by the Yezidis, originates from this ethnogenic myth and symbolically means that they were victims of all nations/non-Yezidis.

Moreover, in traditional religious works, the Yezidis clearly distinguish their millet from others, such as Turks, Tatars, Arabs, Persians. However, it should be stressed here that in these works, there is no word about the Kurds. Significantly, apart from these millets, Christians and Jews are also mentioned. This shows that the term millet in the Yezidi tradition also defines the religious community. These millets are referred to, for example in the Yezidi Morning Prayer and The Hymn to Sheikh Shems. According to stanzas 24-33 of the Qewlê Şessims (Kreyenbroek, Rashow 2005, p. 205, with my little corrections of their English translation):

Here Turke, here Tetere

Ew ẍafilêt bê nedere

Ewan jî Şêşims mfere

Here 'Erebe, here 'Eceme

Ewin ẍafilêt bê kereme

Ewan jî Şêşims pêşqedeme

File ku filene

Bi keşî̧ û abû nene

Ew jî li dû Şêşims diherine.

Cihû ku cihûne

Di selefxor û buxtan û nebûne

Ew jî bi Şêşims bi recûne [...]
All Turks, all Tatars

They are ignorant, without the views

Sheikh Shems is their refuge also

All Arabs, all Persians

They are ignorant, without mystical power

Sheikh Shems is their leader also

The Christians, being Christians

Have priests and monks

They also follow Sheikh Shems.

The Jews, being Jews

Are usurers, slanderers and liars

They also have hopes of Sheikh Shems [...] 
Heştî û duhezar xulayaqete

Şêşims hemûya mor dikete.
Eighty-two thousand creatures

Sheikh Shems 'baptises' them all.

As stated above, the term "millet" originally referred to "religion" and "religious community". The change of the use of this term was undoubtedly connected with the progressive secularisation and the popularity of modern nationalistic ideologies. In case of the Yezidis, the word "millet", as present in the formula "Milete min Êzîd", is nowadays increasingly understood by them as an ethnic, national declaration, but in the previous centuries could mean just the "people of Yezid" or "those, who worship Yezid".

It did not necessarily suggest an ethnic qualification, especially if we take into consideration that the original Yezidi community was not ethnically homogeneous, but consisted of representatives of Kurdish tribes and Arabs such as Sheikh Adi and his family, and perhaps also of some local Assyrians. The first diversity was also present at the linguistic level. Arabic is the language of the oldest Yezidi written documents (secret and very few; Omarkhali 2017, p. 55-72), while the oral "documents" persisted in Kurmanji (permeated by Arabic vocabulary). Thinking about the language criterion as a determinant of nationality, it is worth remembering that although the majority of the Yezidis spoke and speak the Kurdish dialect of Kurmanji, the mother tongue of the inhabitants of Bashique and Bahzani (two important Yezidi villages in Iraqi Kurdistan Region) is still Arabic. In turn, as an effect of migration north, to Transcaucasia, the majority of the Yezidis living in the diaspora there, for several generations have spoken only Russian, Armenian and Georgian.

Understanding "millet" as an equivalent of "nation" in the case of the Yezidis can be seen as an effect of political and cultural pressure applied to the Yezidis to define themselves within the framework of modern ethnic terminology as well as their wish to join the global cultural discourse. This, from the perspective of Western evolutionist and modernist concepts, would indicate that at the moment the Yezidis are at the stage of transition from a religious shepherd community to modern urban society and of forming a "nation" in the Western sense of the word. 


\section{The Quraysh Tradition}

By using the term "millet" the Yezidis qualify themselves as a separate independent group that differs from others. To name their community they use the previously men-

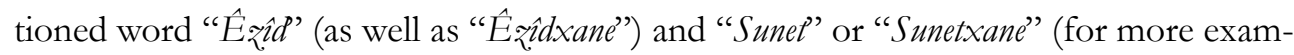
ples see: Rodziewicz 2018 a). Especially important is "Sunet", the word of Arabic origin (from Sunna) which has a long theological tradition. One can find it both in the old poetical Yezidi works as well as in their modern everyday language. It must be strongly emphasised, however, that they use it mainly in the internal discourse (declaring themselves as "Sunel" in the presence of Muslim Sunni neighbours, could give rise to numerous problems).

Sunet means "tradition" (Guraya 1972), and when the Yezidis call themselves "Tradition" or "The House of Tradition" (Sunetxane), they seem to imply that they are the representatives of the true religious tradition, the fundamental norm and practice, which goes back to pre-Islamic times. They see themselves as the descendants of those who did not follow Muhammad's revolution, but who were faithful to the original tradition/religion of Mecca. From the Yezdi perspective, Mecca is not only the holiest place of Islam but primarily the centre of an ancient religious cult.

Therefore, it is no coincidence that the Yezidi holy valley in Iraqi Kurdistan, Lalish, is a topographical copy of Mecca, where they have their own Mount Arafat, Zem Zem spring, and Pira Silat bridge. Thus one can say that Lalish, together with local shrines, and first of all the Sheikh Adi's sanctuary, is supposed to imitate Mecca from the Quraysh times. Nor is it a coincidence that when the Yezidis point to the Sheikh Adi's genealogy, they stress that he belongs to the Quraysh branch, as the descendant of the Umayyad caliph Marwan II (Aloian 2008). At the time when Adi came to Lalish from Baghdad, the local Kurdish tribes still remembered the Umayyads well and even surrounded them with a special cult (Lescot 1975, p. 21; Ahmed 1975, pp. 24-25, 243).

Thus, it does not seem strange to connect the term "Yezid" (and the Yezidis) with the famous Umayyad caliph, Yezid ibn Mu'awiya, who was associated with the denial of the principles of Islam and his love for wine, poetry and mysticism.

Numerous examples of the perception of a Yezid as such a person are present in the Yezidi oral tradition (in hymns and stories, Rodziewicz 2018a, pp. 294-300). However, the Yezidis are reluctant to mention this to foreigners, fearing the repercussions of Muslims, 
especially the Shiites, who accuse Ibn Mu'awiya of the death of Hossein (Ali ibn Abi Talib's son). That is the reason why in conversation with strangers they usually derive their ethnonym from the Avestan yazata ("worthy of veneration"), the Persian izad ("divinity" / "deity") or the Kurdish expression "Ez dam" or "Ez da" pointing to God's act of creation and explaining that they are not "Yezidis", but "Ezdis", because - as one can hear - they worship Angels and God as the Creator of the universe.

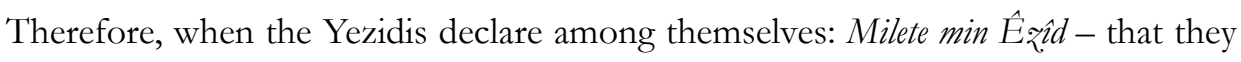
are the "people" or the "nation" of "Yezid" - they treat the Umayyad caliph, also called "Sultan Yezid" (Siltan Êzid) as a symbol of defender of the true religion and tradition connected with old Mecca. This idea is even more visible if one looks at the name of non-Yezidis, whom they refer to as "serî"et" in contrast with the "Sunet". Şerì'et, meaning literally "Law" (from the Arabic Shari'a), denotes those who do not belong to the Yezidi/Sunet community - i.e. heretics, who did not follow the oral tradition, but have their own scriptures and are literate. So, through the distinction between the People of Tradition and the People of Shari'a they recall an old dispute from the very beginnings of Islam that started among the Qurayshites (Hawting 2000, p. 22) from whom Muhammad's clan (Banu Hashim) descended along with the Umayyads.

\section{God's emanation}

To understand the specific and the uniqueness of the Yezidi concept of their community, it should be remembered that this community in its origin was a kind of Sufi brotherhood, Adawiya, founded upon the mystical religious idea that whole the world is permeated by God and his manifestations or emanations that include the Sun, Moon, Stars and other manifestations of natural elements, as well as holy men (esp. Sultan Yezid and Sheikh Adi) and angels - the leader and the first of the divine angels, Tawûsî Melek, for whom the Yezidis are the Chosen People. Thus, the Yezidis, as a whole, are also a kind of emanation of God and Yezid.

As the spiritual head of the Georgian Yezidis, Pir Dima told me:

"The Yezidi religion is characterized by personification. Days are personified, months are personified, Heaven and Earth - personified. Everything is personified except one - evil is not personified. (...) The Yezidis say: »Dine min Sharfadine«, i.e. »My religion Sharfadin« - this is the personification - »Atqata min Sultane Yezide«, i.e. »My faith- 
belief - Sultan Yezid«, and thirdly - Imana min Tausi Malaka«, i.e. »I believe in Tawusi Malak«" (Rodziewicz 2017, p. 38)

The fundament of this concept is the idea of God's secret or essence (sur/sirr), which permeates the universe. Thus, the phrase "Milete min $\hat{E}\{i \hat{\imath} d$ ' expresses a profund metaphysical meaning that the Yezidi millet (and "atqat" as in the quotation above) is a kind of personified emanation of what they call "Sultan Yezid" - one of the manifestations of God who is present or realized by the entire Yezidi community, making it the Ễidxane ("House of Yezid" or the "House of the Yezidis"). Such an approach shows that the traditional Yezidi concept of their community is unique and strongly differs from the understanding of the term "nation", as it is defined in a secular and even atheistic discourse of modern political science, which rejects the mystical perspective. Without this perspective, we are not able to grasp the essence of the Yezidi millet. This is also because for the Yezidis the issue of ethnicity is not even secondary, but is strictly determined by religion.

According to their faith, through the mediation of Adam, they received the divine element, which is passed down from God to Angels and then to the forefather of the Yezidis - Shehid bin Jarr. Its transfer creates a very special mystical millet. Therefore, the Yezidis define themselves not only by the terms " $\hat{E} q \hat{\imath} \hat{d}$ " or "Sunet", but also as the Milletê surê, which can be translated as "Nation of the sur", or even Milletê Xwedê, the "Nation of God", and Milletê Tawsî Melek $\hat{\imath}$ - the "Nation of the Peacock Angel". It is this participation in God's essence that is passed down from generation to generation, making them the "People of the Tradition". We can imagine this concept by the following diagram:

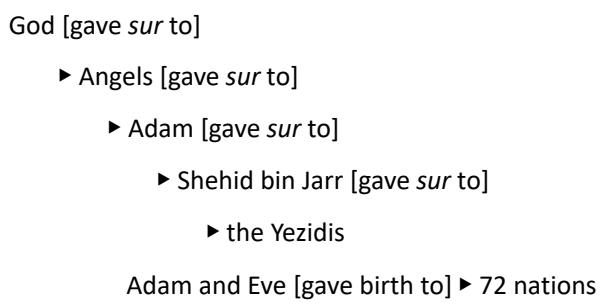

These ideas have found expression in the words of one of the greatest experts of the Yezidi religion, old Feqir Haji from Ba'adra.

In the interview given to Eszter Spät in 2010 he stated: 
"The Qureshi came to the true faith in the name of God. We used to be Qureshi. [...] We were the House of Tradition [Sunetxane], after that we were Qureshi, we were Adawi, we became Daseni, became Mittani, became Babylonians, became Assyrians... [...] We Yezidis are the nation of Layla and Shehid. We have no connection with Eve and Adam. [...] We Yezidis are all the nation of this sur [milletê wê surê]. [...] We have always been the nation of Tawusi Melek and the nation of the sur [Em her milletê Tawsî Melek $\hat{\imath}, \hat{u}$ milletê surê in $]$. [...] We are the children of that sur. We are the House of Tradition" (Spät 2010, pp. 426-436)

That is why the principle of endogamy is still so important to them. The fact that this concept is alive and not limited to ancient myths only was especially visible after the tragedy in Shingal, when the Yezidi authorities clearly stated that children conceived (as a result of rape on Yezidi women) by non-Yezidi have no right to be born (Nicolaus, Yuce 2017, p. 213).

\section{The nation of mystics}

To answer if the Yezidis are a separate nation or not, one should take into consideration that the Yezidi original multi-ethnic community was organised around a religious idea, which after many years resulted in a population with:

- at least 900-years of history,

- their own religion,

- a name for their own religion,

- their own caste system,

- their own sanctuaries and villages,

- their own ethnogenic myth,

- a principle of endogamy,

- their own community name,

- their own political authority (Mir)

- their own religious leader (Baba Sheikh).

Do we know any community with such features and bonded by the strict principle of endogamy that is not a separate nation? It should be emphasised, however, that the application of a term in its Western usage - i.e. "nation" - to the Yezidis, omits and 
falsifies what has been the most important for them for centuries, that is a unique metaphysical perspective. What is more, it engages the Yezidis in terminological disputes that threaten the internal breakdown of their mystical millet.

\section{References}

Ahmed S. (1975), The Yazidis. Their Life and Beliefs, Miami, Coconut Grove

Allison Ch. (2008), "Unbelievable Slowness of Mind”: Yezidi Studies, from Nineteenth to Twentyfirst Century, "Journal of Kurdish Studies", No. 6

Allison Ch. (2014), Living with Labels: New Identities and the Yezidis of Turkey, [in:] Turkey and the Politics of National Identity, (Eds.) Brennan Sh., Herzog M., London, I.B. Tauris

Aloian Z. (2008), Religious and Philosophical Ideas of Shaikh 'Adi b. Musafir, Spånga, Apec

Bedir-Khan S. (1928), The case of Kurdistan against Turkey, Philadelphia, http://www.saradistribution.com/thecaseofkurdistan.htm [24.09.2018]

Braude B. (2014), Foundation myths of the Millet system, [in:] Christians and Jews in the Ottoman empire. The Abridged Edition, (Ed.) Braude B., Boulder, Lynne Rienner Publishers

[Chol], Amir Ba-Yazid al-Amawi (1973): Al-Tavus sanjaq al-Yazid, The Peacock, Sanjaq Yazid, "Alturath Alsha'bi" No 5

Chyet M.L. (2003), Kurdish-English Dictionary, New Heaven-London, Yale University Press

Guraya M.Y. (1972), The Concept of Sunnah a Historical Study, "Islamic Studies" Vol. 11, No. 1

Hawting G.R. (2000), The First Dynasty of Islam. The Umayyad Caliphate AD 661-750, London-New York, Routledge

Kreyenbroek Ph.G., Rashow Kh.J. (2005), God and Sheikh Adi Are Perfect. Sacred Poems and Religious Narratives from the Yezidi Tradition, Wiesbaden, Harrassowitz Verlag

Lescot R. (1975), Enquête sur les Yezidis de Syrie et du Djebel Sindjär, Beyrouth Institut français de Damas]

Murad N. (2017), The Last Girl. My Story of Captivity, and My Fight Against the Islamic State, New York, Tim Duggan Books

Nicolaus P., Yuce S. (2017), Sex-Slavery: One Aspect of the Yezidi Genocide, "Iran and the Caucasus", Vol. 21, No. 2 
Omarkhali Kh. (2017), The Yezidi Religious Textual Tradition: From Oral to Written. Categories, Transmission, Scripturalisation and Canonisation of the Yezidi Oral Religious Texts, Wiesbaden, Harrassowitz Verlag

Pirbari D., Rzgojan R. (2014), K voprosu ob identichnosti ezidov, "Papers of Caucasian Etnology", No. 15

Richardson J. (1777), A Dictionary Persian, Arabic and English, Oxford, Clarendon Press

Rodziewicz A. (2016), The Armenian Portrait of the Peacock. Angel. A polemical review of Garnike Asatrian and Victoria Arakelova's 'The Religion of the Peacock. Angel. The Yezidis and Their Spirit World”, "Fritillaria Kurdica. Bulletin of Kurdish Studies”, No. 13-14

Rodziewicz A. (2017), Revival of the Yezidi Religion in Georgia? Conversations with Dmitri Pirbari - The Head of the Spiritual Council of the Yezidis in Georgia, "Fritillaria Kurdica. Bulletin of Kurdish Studies", No. 16

Rodziewicz A. (2017-2018), W stońcu widze odzwierciedlenie tego, co najwyższe. Rozmowa z. Kerimem Amojewem, „Fritillaria Kurdica. Bulletin of Kurdish Studies”, No. 19-20

Rodziewicz A. (2018a), The Nation of the Sur. The Yezidi Identity Between Modern and Ancient Myth, [in:] Rediscovering Kurdistan's Cultures and Identities: The Call of The Cricket, (ed.) Bocheńska J., New York, Palgrave Macmillan

Rodziewicz A. (2018 b), Jezydzke a droga do Tyflisu. Prayczynek do historii gruziniskich Jezydów, [in:] Kurdystan. Perspektywy badaweze, (Eds.) Rzepka M., Hałaburda M., Kraków, Scientia Plus

Rodziewicz A. (2018c), Kełle, smięte bymny Ježydów, "Przegląd Orientalistyczny”, No. 265-266

Rodziewicz A. (2018d), Qewlê Zebûnî Meksûr, Hymn o Niesz̧ržsnym Rozbitku Qewlê Bê û Elîf, Hymn o Be i A tekst kurmandżi, przeketad, komentary, "Przegląd Orientalistyczny", No. 265-266

Spät E. (2002), Shabid bin Jarr, Forefather of the Yezidis and the Gnostic seed of Seth, "Iran and the Caucasus", No. 6

Spät E. (2010), Late Antique Motifs in Yezidi Oral Tradition, Piscataway, Gorgias Press Ursinus M.O.H. (1993), Millet, [in:] Encyclopaedia of Islam, New Edition, (Eds.) Bosworth C.E. et al., Vol. VII, Leiden-New York, Brill 